\title{
Studies on Phenological Characters of Different Banana Cultivars (Musa) in Visakhapatnam, Andhra Pradesh
}

\author{
Karuna .Y ${ }^{1}$, Dr. K. Kameswara Rao ${ }^{2}$ \\ ${ }^{1}$ Research Scholar, Andhra University, Department of Environmental Science, Visakhapatnam, Andhrapradesh, India \\ ${ }^{2}$ Professor, Andhra University, Department of Environmental Science, Visakhapatnam, Andhrapradesh, India
}

\begin{abstract}
The investigation on "Studies on growth and yield of different cultivars of banana" was carried out during $2014-15$ at 3 different mandals of Visakhapatnam district, Andhra Pradesh, India. Six banana cultivars were taken viz., Karpura Chakkarakeli, Dwarf Cavendish, Robusta, Rashtali, Thella Chakkarakeli and Yenugubontha. The experiment was conducted in field with three replications. The six different banana cultivars were selected for various metric and non metrical observations on vegetative and yield attributing characters were recorded and statistically analyzed. Maximum plant (pseudostem) height, pseudostem girth PCA, Number of suckers at harvest and petiole length was recorded in Yenugu bontha. The highest leaf length, width and total leaves per plant were recorded in Robusta. Similarly, more leaf area, LAI was registered in Robusta. The highest bunch weight and per ha yield was recorded in Robusta whereas, finger length, girth, weight and finger volume were maximum in Yenugu bontha.
\end{abstract}

Keywords: Banana, cultivars,phenology, growth, yield

\section{Introduction}

Banana is the fourth most important food crop in world as well as in India [3]. It is considered as “poor man's apple”. It is a staple food and export commodity. It contributes to the food security of millions of people in the developing world and, when traded in local markets, provides income and employment to the rural populations [11]. India leads the world in banana production with an annual output of about 26509.0 M.T from an area of 776.0 ha (Department of Agriculture and Cooperation Horticulture Division 2013). In India, major banana producing states are Tamil Nadu, Maharashtra, Karnataka, Gujarat, Andhra Pradesh, Assam and Madhya Pradesh. Andhra Pradesh being one of the important states in India growing banana, harbors a wide diversity of crop in both culinary and dessert cultivars. In Andhra Pradesh, the farmers are cultivating local cultivars which are low yielders and the productivity of banana is also low i.e. $35 \mathrm{t} / \mathrm{ha}$ as against $65 \mathrm{t} / \mathrm{ha}$ in Maharashtra. Therefore to improve productivity, a varietal trial in banana with different cultivars was proposed. Banana and plantain is one of the most important fruit crops grown in Andhra Pradesh as well as in Visakhapatnam. Banana is so predominant and popular among people that it is liked both by poor and rich alike. It is also cheap, highly nutritive and easily digestible fruit having refreshing aroma. It has also high production potentiality and profitability. In banana, fruit yield is of great important though consumer acceptance varies from place to place. Commercial banana cultivars are known to be larger in size, weight, length and overall shape and have higher consumer acceptability. Banana owing to its large size and rapid growth rate require relatively large amount of nutrients for high yields of quality fruits.

The present study is on Phenology, refers to the vegetative and reproductive development cycles of different banana cultivars as determined by climate and in particular temperature. Leaf area is an important component that is closely related to the physiological processes controlling dry matter production and yield. Leaf area has been shown to influence the radiant energy interception, an important photosynthetic parameter in crop plants, showing positive relationship with net photosynthetic activity [20]. Leaf area is one of the growth parameters also indicates the size of photosynthesizing apparatus. Leaf area (LA) is a fundamental determinant of the total photosynthesis by plant. Leaf area showed a positive relationship with net photosynthetic activity. In banana, higher amount of LA on shoot coincide with the emergence of bunches (inflorescence) from the top of the pseudo stem. After this no new leaves are produced on that shoot because the bunch is terminal as the older leaves senescence [22]. Leaf area index (LAI) is an important source in manufacturing photo assimilates for determining dry matter accumulation and crop yield. An increase in LAI results in better utilization of solar energy. It is a positive index with direct influence of on plant growth. Specific leaf weight (SLW) is useful in understanding the means of assimilates in leaf expansion. The SLW is a measure of LA per unit dry weight and it varies with cultivar, leaf position, growth stage and environmental condition by Veerawirdh [24]. There is no authentic information available on morphological, phenological and yield attributing variations required for an ideal production by the different banana cultivars under Visakhapatnam agro climatic conditions, so, the investigation was under taken on banana cultivar varieties to describe various phenological characters and to work out correlation of different characters with yield.

\section{Materials and Methods}

\section{A. Experimental Site}

An experiment was conducted to study the growth and development of different cultivars of banana for recommending suitable cultivar with higher yield for 


\section{International Journal of Science and Research (IJSR) \\ ISSN (Online): 2319-7064}

Index Copernicus Value (2013): 6.14 | Impact Factor (2015): 6.391

cultivation under coastal areas of Andhra Pradesh. The study was carried out during 2014-15 at 3different mandals (Anandapuram, Payakaraopeta and S. Rayavaram) of Visakhapatnam district, Andhra Pradesh, India. Six banana cultivars were collected viz., Karpura chakkerakeli/ poovan, Dwarf Cavendish/ potti arati, Robusta/ pedda pacha ariti/ Grand naine, Rashtali/ Amrutha pani, Tella chakkerakeli and Yenugu bontha/ Monthan which are commercially cultivated throughout India. The studies consisted of the plants were randomly selected and biometrical observation on vegetative and yield attributing characters were recorded and statistically analyzed. Observations were taken from the second month after planting at 15 says interval. An experiment was conducted to study the growth and development of different cultivars of banana for recommending suitable cultivar with higher yield for cultivation under coastal areas of Andhra Pradesh. The experiments were conducted under Flood furrow irrigated system (Weekly once in monsoon and Weekly twice in summer) conditions. Throughout the experiment, the mean rainfall was $538.8 \mathrm{~mm}$ and 742.5 for 2014 and 2015 respectively. The mean maximum and minimum temperatures recorded were $34.8^{\circ} \mathrm{C}$ and $18.5^{\circ} \mathrm{C}$ in 2014 and $36.4^{\circ} \mathrm{C}$ and $19.3^{\circ} \mathrm{C}$ in 2015 . The mean maximum and minimum relative humidity was 89.7 and $62.5 \%$ during 2014 and 87.5 and $61.7 \%$ during 2015. Mean bright sunshine hours per day was 4.35 during the experimental period.

The soil type was sandy loam in texture. The soils were neutral (pH 7.05 and 7.16) with low soluble salts (EC 0.264 and $\left.0.253 \mathrm{~d} \mathrm{Sm}^{-1}\right)$, medium in organic carbon content $(0.52$ and $0.45 \%$ ), low in available nitrogen (208 and $232 \mathrm{~kg} / \mathrm{ha}$ ), medium in available phosphorus (14.6 and $15.2 \mathrm{~kg} / \mathrm{ha})$ and high in available potassium (610 and $650 \mathrm{~kg} / \mathrm{ha})$ for 2014 and 2015 , respectively.

\section{B. Data collection}

\section{1) Morphological properties}

Pseudo stem height was measured from the base of the plant to the top of the plant and girth of pseudo stem was measured around the circumference using meter tape. The pseudo cross sectional area (PCA) were measured by girth $^{2} / 4 \pi$. Number of leaf per plant at harvest was counted in each plant at the time of harvest while number of suckers until time of shooting was recorded by counting the number of suckers produced by each plant upto shooting. Leaf length was measured from leaf blade base to the tip of the leaf and leaf width was measured at the point where the maximum breadth exists in the leaf at the time of flowering in each plant using tape meter. Time interval between successive leaf emergencies was recorded in days taking into consideration the emergence day of preceding leaf. Total leaf area was estimated nondestructively by multiplying the product of length and breadth of the third leaf by the factor 0.8 and number of leaves and expressed as $\mathrm{m}^{2} /$ plant The leaf area index of functional leaves was obtained by leaf area per plant divided by ground area occupied by the plant Phyllochron, the time interval between the appearances of two successive leaves (day's leaf ${ }^{1}$ ) on the developing pseudostem was recorded. The specific leaf weight $(\mathrm{mg}$ $\mathrm{cm}^{-2}$ ) was obtained by leaf dry weight divided by leaf area per plant. At harvest stage, total crop duration (planting to harvest) was recorded and expressed in days.

\section{2) Fruit Yield and Yield Components}

Bunches were harvested at the green maturity stage. Bunch weight was measured using field balance after taking the bunch from the banana plant and peduncle length, width was measured. The number of hands per bunch was recorded after counting hands in each bunch. Then after hands were separated from bunches and hands were weighted in Kilograms and fingers per hand in each hand were counted. All fingers are separated from a hand weighted and divided to the number of fingers counted in each hand to obtain finger weight in grams and fruit yield per hectare was obtained by multiplying number of fruits produced in a hectare by main weight of fingers and converted to ton per hectare. Finger length and finger diameter were measured in centimeter using ruler taking randomly selected ten fingers from each bunch obtained from each plant in each replication. The data obtained was analyzed statistically.

\section{Results and Discussion}

\section{A. Growth Characters}

Table 1: Growth (pseudo stem) Characters of different cultivars of banana

\begin{tabular}{|c|c|c|c|c|}
\hline Cultivars & $\begin{array}{c}\text { Pseudo } \\
\text { stem height } \\
(\mathrm{m})\end{array}$ & $\begin{array}{c}\text { Pseudo } \\
\text { stem girth } \\
(\mathrm{cm})\end{array}$ & $\begin{array}{c}\text { PCA } \\
\left(\mathrm{cm}^{2}\right)\end{array}$ & $\begin{array}{c}\text { No of } \\
\text { suckers } \\
\text { at } \\
\text { harvest }\end{array}$ \\
\hline Karpura chakkerakeli & 2.78 & 54.16 & 234.6 & 7.10 \\
\hline Dwarf Cavendish & 2.63 & 52.33 & 218.2 & 6.75 \\
\hline Robusta & 2.84 & 56.50 & 254.3 & 7.33 \\
\hline Rashtali & 3.25 & 61.50 & 301.3 & 5.54 \\
\hline Tella chakkerakeli & 2,96 & 58.50 & 272.6 & 5.25 \\
\hline Bontha & 3.46 & 62.33 & 309.5 & 7.50 \\
\hline SE m+- & 0.8 & 0.89 & 2.76 & 0.14 \\
\hline CD(P=0.05) & 0.25 & 2.74 & 5.53 & 0.19 \\
\hline
\end{tabular}

In banana plants, moderate height and more girth rate desirable as these traits reflect on the bunch size and other related characters, apart from providing better anchorage. It is evident from the data (table I) that pseudostem height ranged from $2.63 \mathrm{~m}$ to $3.46 \mathrm{~m}$. Yenugu Bontha $(3.46 \mathrm{~m})$ recorded higher pseudostem height and it was on par with Rashtali (3.25m), Robusta (3.18m), Thella chakkerakeli $(2.96 \mathrm{~m})$ and Karpura chakkerakeli $(3.36 \mathrm{~m})$. The lowest plant height was recorded in Dwarf Cavendish (2.63m). Among different varieties tested, Bontha $(62.33 \mathrm{~cm})$ recorded significantly higher pseudostem girth followed by Rashtali $(61.50 \mathrm{~cm})$, Thella chakkerakeli $(58.50 \mathrm{~cm})$, Robusta $(56.50 \mathrm{~cm})$, Karpura chakkerakeli $(54.16 \mathrm{~cm})$ and Dwarf Cavendish $(52.33 \mathrm{~cm})$ showed lowest pseudostem girth at shooing stage. The maximum PCA was recorded in Yenugu Bontha $\left(309.56 \mathrm{~cm}^{2}\right)$ followed by Rashtali $\left(301.37 \mathrm{~cm}^{2}\right)$, $\left(272.68 \mathrm{~cm}^{2}\right)$, Robusta $\left(254.36 \mathrm{~cm}^{2}\right)$, Karpura chakkerakeli $\left(234.66 \mathrm{~cm}^{2}\right)$ and minimum PCA was in Dwarf Cavendish $\left(218.20 \mathrm{~cm}^{2}\right)$.The utmost number of suckers at harvest was recorded in Yenugu bontha (7.50) followed by Robusta (7.33), Karpura chakkerakeli (7.10), Dwarf Cavendish 


\section{International Journal of Science and Research (IJSR) \\ ISSN (Online): 2319-7064 \\ Index Copernicus Value (2013): 6.14 | Impact Factor (2015): 6.391}

(6.75), Rashtali (5.54) and least was in Thella chakkerakeli (5.25). Similarly, significantly higher number of total leaves was recorded in Robusta (29.25). The intermediate values were recorded in Rashtali (27.23), Karpoora chakkerakeli (26.23), Dwarf Cavendish (25.16) and Bontha (24.60) at shooting stage which was at par with each other. The lowest number of total leaves was obtained in Thella chakkerakeli (23.50). The maximum petiole length was recorded in Bontha $(37.50 \mathrm{~cm})$ and the minimum was in Karpura chakkerakeli $(33.56 \mathrm{~cm})$.

Table 2: Growth (leaf) Characters of different cultivars of banana

\begin{tabular}{|c|c|c|c|c|c|c|c|}
\hline Cultivars & $\begin{array}{c}\text { Leaf } \\
\text { length } \\
(\mathrm{cm})\end{array}$ & $\begin{array}{c}\text { Leaf } \\
\text { width } \\
(\mathrm{cm})\end{array}$ & $\begin{array}{c}\text { Total } \\
\text { leaves/ } \\
\text { plant }\end{array}$ & $\begin{array}{c}\text { Leaf } \\
\text { area } \\
\left(\mathrm{m}^{2}\right. \\
\text { /plant }\end{array}$ & LAI & $\begin{array}{c}\text { Phyllo } \\
\text { chron } \\
\text { (days })\end{array}$ & $\begin{array}{c}\text { Specific } \\
\text { leaf } \\
\text { weight } \\
(\mathrm{g} / \mathrm{m} 2)\end{array}$ \\
\hline $\begin{array}{c}\text { Karpura } \\
\text { chakkerakeli }\end{array}$ & 143.2 & 39.6 & 26.23 & 12.17 & 3.04 & 7.0 & 1.15 \\
\hline $\begin{array}{c}\text { Dwarf } \\
\text { Cavendish }\end{array}$ & 142.2 & 38.2 & 25.16 & 11.19 & 4.97 & 6.6 & 1.20 \\
\hline Robusta & 159.1 & 43.0 & 29.25 & 16.07 & 5.02 & 7.3 & 1.28 \\
\hline Rashtali & 154.2 & 43.2 & 27.23 & 14.83 & 3.70 & 6.9 & 1.18 \\
\hline $\begin{array}{c}\text { Tella } \\
\text { chakkerakeli }\end{array}$ & 155.6 & 40.6 & 23.50 & 11.32 & 3.53 & 6.7 & 1.22 \\
\hline Bontha & 152.3 & 42.4 & 24.60 & 12.71 & 3.17 & 7.1 & 1.24 \\
\hline SEm+- & 2.48 & 0.72 & 0.21 & 0.32 & 0.16 & 0.18 & 0.18 \\
\hline CD(P=0.05) & 5.98 & 2.63 & 0.64 & 0.98 & 0.74 & 0.58 & 0.63 \\
\hline
\end{tabular}

The maximum leaf length and width was recorded in Robusta (159.12, 43.09). The minimum was recorded in dwarf Cavendish $(142.25,38.26)$ respectively. Robusta (16.07 sq.m plant-1) recorded significantly higher leaf area over other cultivars followed by Rashtali (14.83sq.m plant1), Bontha (12.71), Karpura chakkerakeli (12.17 sq.m plant1) and Thella chakkerakeli (11.32sq.m plant-1). The lowest leaf area (11.19sq.m plant-1) was recorded in Dwarf Cavendish. Similarly, LAI was higher in Robusta (5.02) followed by Dwarf Cavendish (4.97), Rashtali (3.70), Thella chakkerakeli (3.53), Bontha (3.17) and the lowest LAI was recorded in Karpura chakkerakeli (3.04). Phyllochron or rate of leaf production is an important factor to be considered during vegetative growth [7]. The maximum phyllochron was observed in Robusta (7.3) and the minimum was in Dwarf Cavendish (6.6). The highest Specific leaf weight (SLW) was observed in Robusta $\left(1.28 \mathrm{~g} / \mathrm{m}^{2}\right)$ and lowest SLW content was observed in Karpura chakkerakeli $\left(1.15 \mathrm{~g} / \mathrm{m}^{2}\right)$ (table II).

\section{B. Crop Duration}

Table 3: Crop duration and plant crop cycle of different cultivars of banana

\begin{tabular}{|c|c|c|c|}
\hline Cultivars & $\begin{array}{c}\text { Days to } \\
\text { shooting } \\
\text { (days) }\end{array}$ & $\begin{array}{c}\text { Flower } \\
\text { emergence to } \\
\text { harvest (days) }\end{array}$ & $\begin{array}{c}\text { Total crop } \\
\text { duration } \\
\text { (days) }\end{array}$ \\
\hline Karpura chakkerakeli & 224.3 & 108.2 & 332.5 \\
\hline Dwarf Cavendish & 229.3 & 116.4 & 345.7 \\
\hline Robusta & 230.6 & 117.9 & 348.5 \\
\hline Rashtali & 239.2 & 115.3 & 353.5 \\
\hline Tella chakkerakeli & 228.50 & 109.3 & 337.8 \\
\hline Bontha & 243.50 & 102.1 & 345.6 \\
\hline SEm+- & 1.64 & 1.46 & 1.82 \\
\hline CD $(\mathrm{P}=0.05)$ & 5.02 & 4.86 & 5.65 \\
\hline
\end{tabular}

In crop duration of different banana cultivar plants (presented in table 3), early shooting (days to planting to inflorescence emergence) was observed in Karpura chakkerakeli (224.3) whereas, late shooting was recorded in Bontha (243.50). With regards to days taken to harvest (from inflorescence emergence to harvesting) significantly early harvest was observed in Bontha (107.1) whereas Robusta (117.9 days) recorded significantly late harvest. The highest Total crop duration in Robusta (353.5 days) and lowest were recorded in 332.5 during crop cycle of different banana cultivars. The present results confirmed the report of Patel [13], Rajmanickam and Rajmohan [14], Hazarika and Ansari [4], Kavitha et al. [5], Badgujar et al. [1], Raskar [16], Orellana [12], Sirisena [18].

\section{Inflorescence or male bud Characters}

In table 4 the maximum peduncle length $(56.70 \mathrm{~cm})$ and peduncle width $(19.50 \mathrm{~cm})$ was recorded in Bontha. The minimum peduncle length was recorded in Karpura chakkerakeli $(45.50 \mathrm{~cm})$ and peduncle width was recorded in Dwarf Cavendish $(15.75 \mathrm{~cm})$. The highest male bud size (23.90 cm length and $34.75 \mathrm{~cm}$ girth) was observed in Bontha and the lowest male bud size $(20.75 \mathrm{~cm}$ length and $28.25 \mathrm{~cm}$ girth) was observed in karpura chakkerakeli. Similar finding has also been reported by Rajmanickam and Rajmohan [10], Tenkovano [21], D. Kumar [6], Singh [19], Mandal [8] and Uma et al., [23].

Table 4: Inflorescence or male bud of different banana cultivars

\begin{tabular}{|c|c|c|c|c|}
\hline Cultivars & $\begin{array}{c}\text { Peduncle } \\
\text { length }(\mathrm{cm})\end{array}$ & $\begin{array}{c}\text { Peduncle } \\
\text { width }(\mathrm{cm})\end{array}$ & $\begin{array}{c}\text { Male bud } \\
\text { length }(\mathrm{cm})\end{array}$ & $\begin{array}{c}\text { Male bud } \\
\text { girth }(\mathrm{cm})\end{array}$ \\
\hline $\begin{array}{c}\text { Karpura } \\
\text { chakkerakeli }\end{array}$ & 45.50 & 16.75 & 20.75 & 28.25 \\
\hline $\begin{array}{c}\text { Dwarf } \\
\text { Cavendish }\end{array}$ & 46.25 & 15.75 & 21.55 & 29.50 \\
\hline Robusta & 52.65 & 18.50 & 23.50 & 33.50 \\
\hline Rashtali & 48.35 & 17.75 & 22.65 & 30.25 \\
\hline $\begin{array}{c}\text { Tella } \\
\text { chakkerakeli }\end{array}$ & 51.25 & 16.50 & 22.45 & 31.25 \\
\hline Bontha & 56.70 & 19.50 & 23.90 & 35.75 \\
\hline SEm+- & 1.86 & 0.69 & 0.75 & 1.21 \\
\hline $\mathrm{CD}(\mathrm{P}=0.05)$ & 4.10 & 1.44 & 1.57 & 2,31 \\
\hline
\end{tabular}




\section{International Journal of Science and Research (IJSR) \\ ISSN (Online): 2319-7064}

Index Copernicus Value (2013): 6.14 | Impact Factor (2015): 6.391

Table 5: FRUIT Yield and yield characters of different cultivars of banana

\begin{tabular}{|c|c|c|c|c|c|c|c|c|c|c|c|}
\hline Cultivars & $\begin{array}{c}\text { Bunch } \\
\text { weight } \\
(\mathrm{Kg})\end{array}$ & $\begin{array}{c}\text { Bunch } \\
\text { length } \\
(\mathrm{cm})\end{array}$ & $\begin{array}{c}\text { Bunch } \\
\text { girth } \\
(\mathrm{cm})\end{array}$ & $\begin{array}{c}\text { Number of } \\
\text { hands/ bunch }\end{array}$ & $\begin{array}{c}\text { Fingers per } \\
\text { Hand }\left(2^{\text {nd }}\right)\end{array}$ & $\begin{array}{c}\text { Total fruits } \\
\text { per bunch }\end{array}$ & $\begin{array}{c}\text { Finger } \\
\text { length }(\mathrm{cm})\end{array}$ & $\begin{array}{c}\text { Finger } \\
\text { girth } \\
(\mathrm{cm})\end{array}$ & $\begin{array}{c}\text { Finger } \\
\text { weight } \\
(\mathrm{g})\end{array}$ & $\begin{array}{c}\text { Finger } \\
\text { volume } \\
(\mathrm{cc})\end{array}$ & $\begin{array}{c}\text { Yield } \\
\left(\mathrm{t} / \mathrm{a}{ }^{1}\right)\end{array}$ \\
\hline $\begin{array}{c}\text { Karpura } \\
\text { chakkerakeli }\end{array}$ & 19.71 & 42.2 & 114.5 & 9.57 & 15.76 & 150.8 & 14.2 & 12.5 & 95.25 & 103.2 & 37.35 \\
\hline $\begin{array}{c}\text { Dwarf } \\
\text { Cavendish }\end{array}$ & 24.40 & 41.5 & 119.4 & 9.21 & 14.36 & 132.2 & 16.5 & 11.8 & 105.6 & 117.2 & 35.62 \\
\hline Robusta & 28.50 & 48.5 & 124.5 & 10.25 & 15.98 & 162.7 & 19.5 & 13.8 & 142.6 & 162.2 & 39.42 \\
\hline Rashtali & 23.42 & 46.3 & 122.4 & 9.46 & 12.90 & 122.0 & 15.7 & 14.2 & 135.5 & 148.5 & 36.12 \\
\hline $\begin{array}{c}\text { Tella } \\
\text { chakkerakeli }\end{array}$ & 18.71 & 39.8 & 121.6 & 7.42 & 12.33 & 91.4 & 15.2 & 13.5 & 129.7 & 142.7 & 34.57 \\
\hline Bontha & 21.50 & 40.6 & 128.5 & 7.66 & 11.46 & 87.7 & 22.5 & 18.7 & 248.0 & 252.5 & 38.16 \\
\hline SEm+- & 0.34 & 0.46 & 0.36 & 0.44 & 0.54 & 5.06 & 0.39 & 0.30 & 3.03 & 2.56 & 1.25 \\
\hline CD(P=0.05) & 1.06 & 1.23 & 1.28 & 1.36 & 1.65 & 15.23 & 1.20 & 0.92 & 9.14 & 8.45 & 3.63 \\
\hline
\end{tabular}

\section{Yeild characters}

It is evident from the data (table 5) that among all the cultivars, Robusta produced more number of hands (10.25) and lowest numbers of hands were recorded in Thella chakkerakeli (7.42). Bunch weight ranged from $28.50 \mathrm{~kg}$ to $18.71 \mathrm{~kg}$. The highest bunch weight $(28.50 \mathrm{~kg})$ was observed in Robusta and the lowest bunch weight (18.71 kg) was observed in Thella chakkerakeli. The maximum bunch length $(48.50 \mathrm{~cm})$ and bunch girth $128.5 \mathrm{~cm})$ was recorded in Bontha. The minimum bunch length $(39.80 \mathrm{~cm})$ was recorded in Thella chakkerakeli and bunch girth $(114.5 \mathrm{~cm})$ was recorded in karpura chakkerakeli. Robusta (15.98) significantly recorded highest number of fingers per hand. Bontha (11.46) recorded lesser number of fingers per hand.

Finger length ranged from $14.2 \mathrm{~cm}$ to $22.5 \mathrm{~cm}$. Higher finger length was observed in Bontha $(22.5 \mathrm{~cm})$. Thella chakkerakeli $(15.2 \mathrm{~cm})$ and Karpura chakkerakeli $(14.2 \mathrm{~cm})$ recorded minimum finger length. Significance difference was observed among the different cultivars. Lowest finger girth was recorded in Dwarf Cavendish $(11.8 \mathrm{~cm})$ and maximum finger girth was recorded in Bontha $(18.7 \mathrm{~cm})$. Total number of fingers per bunch was significantly highest in Robusta (162.7) and lowest fruits per bunch were recorded in Bontha (87.78). Finger weight was significantly highest in Bontha (248.08g) followed by Robusta (142.64g), Rashtali (135.50g), Thella chakkerakeli (123.73g) and Dwarf Cavendish (105.63g). Minimum finger weight was recorded in Karpura chakkerakeli $(95.25 \mathrm{~g})$. The yield per hectare ranged from $34.57 \mathrm{t} / \mathrm{ha}$ to $39.42 \mathrm{t} / \mathrm{ha}$. Robusta (39.42t/ha) recorded significantly higher yield than other cultivars and followed by Bontha (38.16t/ha), Karpura chakkerakeli (37.35t/ha), Rashtali (36.12t/ha), and Dwarf Cavendish (35.62t/ha) which were at par with each other. The lowest yield was recorded in Thella chakkrakeli (34.57t/ha). The results obtained in the present study with respect to yield and yield attributes corroborate with the results of Robinson and Nel [17], Medhi [9], Kumar [7] Baruah et al. [2], Njuguna et al. [10], Rajmanickam and Rajmohan [15] who reported similar variation among different culinary cultivars.

\section{Conclusion}

Keeping the higher productivity in view, banana cv. Robusta and Bontha can be recommended for commercial cultivation in Visakhapatnam, Andhra Pradesh. The Robusta has become one of the most popular desert varieties for commercial plantations. Its characteristic medium height and large fruit yields make it an ideal for commercial agriculture.

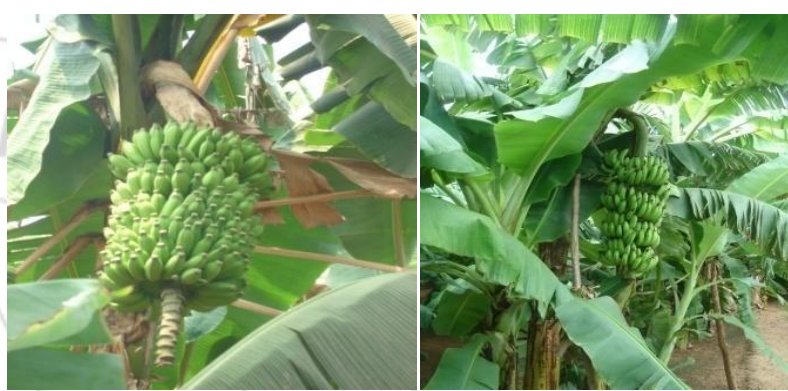

Figure 1: Karpoora chakkerakeli Figure 2: Dwarf cavendish

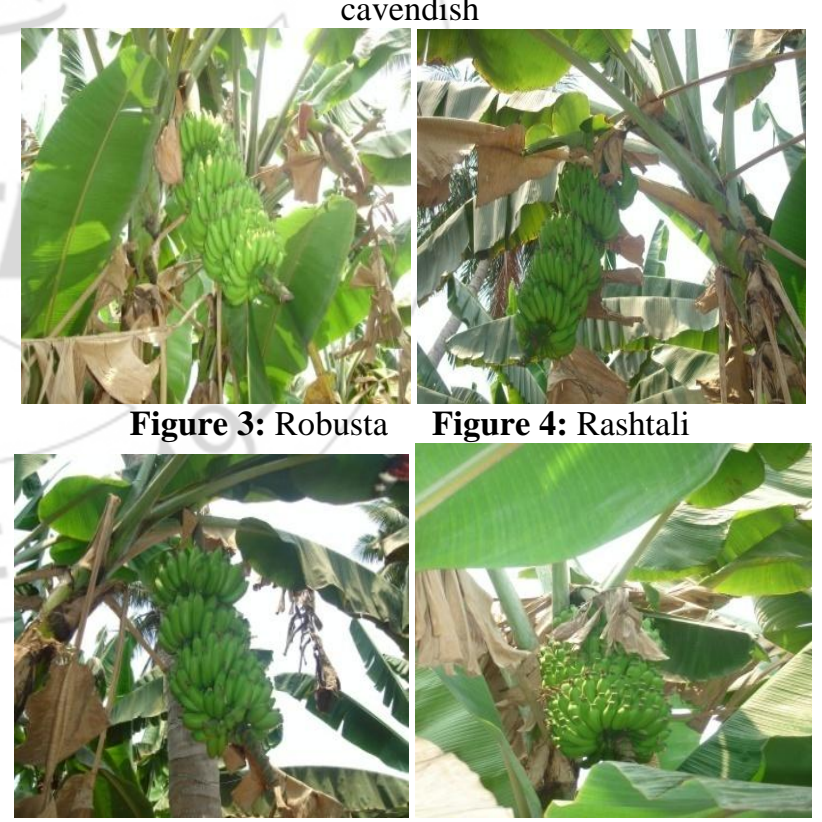

Figure 5: Thella chakkera keli Figure 6: Yenugu Bontha

\section{References}

[1] Badgujar, C S.M. Dusane and S.Desmukh, (2004) Influence of plant spacing on growth, maturity and yield of Grand Naine (AAA) banana. South Indian Hort., 52(1-6): 13-17.

[2] Baruah, K., Jyothi Bhaskar Sarma and Sut. Debajit (2007).Genetic variability in banana cultivars under Assam conditions. Indian Journal of Horticulture, 64(3) : 282-85. 


\section{International Journal of Science and Research (IJSR) \\ ISSN (Online): 2319-7064}

Index Copernicus Value (2013): 6.14 | Impact Factor (2015): 6.391

[3] Ganapathi TR, Suprasanna PS, Bapat VA, Kulkarni VM, Rao PS (1999) Somatic embryogenesis and plant regeneration from male flower buds in banana. Current Science 76, 1228-1231.

[4] Hazarika B, and S.Ansari, (2010) Effect of integrated nutrient management on growth and yield of banana cv. Jahaji. Indian J. Hort., 67(2): 270-273.

[5] Kavitha, P T. Balamohan, D. Veeraragavathatham, and K.Poornima, (2009) Genetic variability and correlation in ecotypes of Nendran banana. Banana New Innovation, Westville Publishing House, New Delhi, 91 -98 .

[6] Kumar D and V.Panday, (2010) Relationship of pseudostem cross sectional area with bunch weight, fruit quality and nutrient status in banana cv. Rasthali ( Pathkapoora-AAB ). Indian J. Hort., 67(1): 26-29.

[7] Kumar, D V. Panday and K.Anjaneyulu, (2008) Effect of planting density and nutrient management on growth, yield and quality of micropropagated banana $\mathrm{cv}$. Rasthali. Indian J. Hort., 65(3): 272-276.

[8] Mandal B, and S.Sharma, (2001) Effect of leaf pruning on the growth and yield of banana cv. Alpan. The Hort. J., 14(1): 7-11.

[9] Medhi, G. (1994). Performance of some cultivars of Banana (Musa paradisiaca) in Assam. Haryana Journal of Horticulture Science, 23 : 181-85.

[10] Njuguna, J., F. Nguthi, S. Wepukhulu, F. Wambugu, D. Gitau, M. Karuoya and D. Karamura (2008). Introduction and evaluation of improved banana cultivars for agronomic and yield characteristics in Kenya. Africian Crop Scince Journal, 16(1) : 35-40. 11.

[11] Olivia Saha Roy, Pranay Bantawa, Swapan Kumar Ghosh, Jaime A.Teixeira da Silva, Partha DebGhosh and Tapan Kumar Monda (2010) Micropropagation and Field Performance of 'Malbhog' (Musa paradisiaca, AAB group): A Popular Banana Cultivar with High Keeping Quality of North East India. Tree and Forestry Science and Biotechnology Global Science Books.

[12] Orellana P, I. Bermudez, G. Rodriguez, and N.Rodriguez, Evaluation of the agronomic characteristics of plantain hybrids (Musa spp.). INFOMUSA, 2002, 11(1): 34-35.

[13] Patel CM, N.L. Patel, S.S. Gaikwad, and S.J.Patil, (2011) Effect of post shooting treatments on yield and its attributes of banana cv. Grand Naine. Green Farming, 2(2): 210-212.

[14] Rajamanickam C and K.Rajmohan, (2005) Intra clonal variation in Musa (AAB) "Nendran". South Indian Hort., 53(1-6): 195-204.

[15] Rajamanickam, C. and K. Rajmohan (2010). Variability studies in Palayankodan ecotypes (AAB genomic group) of banana (Musa spp.). Journal of Horticultural Sciences, 5(2) : 109-13.

[16]Raskar, BS (2003) Effect of planting technique and fertigation on growth, yield and quality of banana. Indian J. of Agronomy, 48(3): 235-237.

[17] Robinson, J. C. and D. J. Nel (1985). Comparative morphology, phenology and product potential of banana cultivars "Dwarf Cavendish and Williams" in the eastern transvaal lowland. Scientia Horticulture, 25(2) : 149-61.

[18] Sirisena, J and S.G.Senanayake, (2000) Estimation of variability parameters within "Mysore" banana clones and their implication for crop improvement. Scientia Hortl, 84: 49-66.

[19] Singh, M (2010) Evaluation and economics of different intercrops in banana. Indian J. Hort., 67(2): 267-269.

[20] Surendar,KK, D. Durga Devi, I. Ravi, P. Jeyakumar and K. velayudham (2013) Effect of water deficit on relationship between yield and physiological attributes of banana cultivarsand hybrids.vol. 8,6116-6125.

[21] Tenkovano A and K.Baiyeri, (2007) Adaptation pattern and yield stability of banana and plantain genotypes grown in contrasting agroecologies in Nigeria. African Crop Science Conference Proceedings, 8: 377-384.

[22] Turner DW (1998). The impact of environmental factors on the development and productivity of bananas and plantains. In Proceedings of the 13th ACORBAT meeting, Guayaquil, Ecuador, (Ed. L. H. Arizaga). Ecuador, CONABAN. pp.635-663.

[23] Uma S, M. Dayarani, H.P. Singh, B. Shyam, and S.Sathiamoorthy, (2000) Studies on genetic variability in banana Silk sub group (AAB). Indian J. Hort. , 57(2): 106-109.

[24] Veerawirdh J(1974). Growth analysis of various soybean varieties as affected by different spacing. M.Sc. (Ag.) Thesis Tamil Nadu Agricultural University, Coimbatore. 